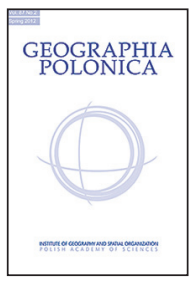

\title{
A SCENARIO OF RURAL DEVELOPMENT FROM THE PERSPECTIVE OF MULTIFUNCTIONAL AGRICULTURE IN THE EU: A CRITICAL REFLECTION ON THE CZECH REPUBLIC
}

\author{
EVA CUDLINOVA*, MARTIN PELUCHA ** \\ Economic Faculty of South Bohemian University, \\ Studentska 13, Ceske Budejovice, Post Code: 37005, Czech Republic \\ E-mails: "evacu@centrum.cz, ${ }^{* *}$ martinpelucha@seznam.cz
}

\begin{abstract}
Multifunctional agriculture is nowadays a key issue of the second pillar of the EU's Common Agriculture Policy. The concept of multifunctional agriculture is also seen as a possible development scenario for EU rural areas. But the question of the territorial impact of such policy tools has been raised. The main aim of the paper is to analyze the application of the multifuncionality concept in selected EU countries. In particular, the paper engages in a critical reflection of multifunctional agriculture as a specific scenario for rural development in the Czech Republic in the previous period of the programme, $2004-2006$.
\end{abstract}

Key words: agriculture, rural development, multifunctionality

\section{INTRODUCTION}

Nowadays European agriculture and rural areas are confronted with a number of critical challenges. These include: the process of market liberalization; economic crises; the emergence of low cost producing countries on the world market; the consequences of EU enlargement; changes in consumer preferences; the emergence of new consumer concerns; and the conjunction of nature, tradition, recreation, culture and the historical context of land use. In this context, the challenge for the agricultural community is to redefine its position in current society and its mission in the rural economy (Lowe et al. 2002; Johnson 2001; Bureau, Mahé 2008). The new role and perspective of agriculture is often seen in the multifuncionality of the agriculture (Wilson 2007; Marsden et al. 2002).

The concept of multifunctional agriculture is also seen as a possible development scenario for EU rural areas (Mahé et al. 1999; Tangermann 2006). But a question has been raised regarding the territorial impact of such policy tools which aim to support the agricultural dimension of rural development (Dwyer et al. 2007; Shucksmith et al. 2005). The main goal of this paper is to analyze the application of the multifuncionality concept in selected EU countries. The paper, in particular, attempts to undertake a critical reflection of multifunctional agriculture as a specific scenario for rural development in the Czech Republic in the previous period of the programme, 2004-2006.

The paper argues that the concept of multifunctional agriculture is very difficult to evaluate in broad terms because of the different approaches and understanding in selected EU countries. Moreover, there is a problem in practical terms because of public spending and reached appropriate level of statistical indicators, especially in the case of the Czech Republic. We demonstrate the complexity of 
this issue in the case of the Horizontal Rural Development Plan 2004-2006 of the Czech Republic, which represented approximately $75 \%$ of the expenditure of the EU CAP II pillar. A specific research question for the individual case of the Czech Republic is related to how this programme is implemented: "to what extent has the programme contributed to the maintenance of farm and off-farm employment?"

This paper originates from a number of pieces of research that the authors have undertaken in the Czech Republic. These include explorative studies in specific thematic evaluations (conducted for the Czech Ministry of Agriculture and the Ministry for Regional Development) and currently in a research project "Capitalisation of research results on the multifuncionality of agriculture and rural areas (acronym Multagri)" financed by the EU and which began in 2004.

The paper first sets out the context of the multifuncionality concept in the agricultural sector. It then analyses the position of selected EU countries in relation to multifunctional agriculture in broad terms. These two parts of the paper represent the theoretical and methodological analysis of multifunctional agriculture. The second part of the paper aims to analyse the concrete situation of multifunctional agriculture in the Czech Republic. Specific attention is paid to the way in which the EU CAP II. pillar supports employment in the Czech Republic. Finally, the concluding discussion highlights the key issues for the multifuncionality concept and mutual relations in relation to EU CAP reform.

\section{THE BACKGROUND OF THE ECONOMIC RATIONALITY OF MULTIFUNCTIONAL AGRICULTURE IN RELATION TO RURAL DEVELOPMENT}

The EU CAP reform is a long term process and the concept of multifuncionality is often seen as an alternative way of conserving a certain level of agricultural subsidies. Therefore, there is a question of whether the issue of multifuncionality is specific to the agricultural sector. Wilson (2007, p. 181) has pointed out that apart from multifunctional agriculture, there has also emerged a fruitful debate about multifunctional urban planning, where the major problem being addressed is also the different uses of land. Wilson stressed that urban functions and spaces have gradually become more "monofunctional", with an increasing separation between workplace and residential functions, and that there is a need to redress this by promoting "multifunctional" or mixed use (Wilson, 2007, pp. 181). In this sense, the concept of multifunctionality is not a specificity of the agriculture sector.

According to the OECD (2001), a number of issues exist in relation to an agriculture sector that is not equal to the other sectors. These issues explain why multifunctionality has become policy relevant, especially in agriculture. The OECD identifies several issues, such as the geographical dispersion of farm enterprises, and others to the political decision making process and the high levels of support and protection that continues to be provided to the sector (OECD 2001, pp. 12). The OECD also distinguishes between two interpretations of multifunctionality: one with a "positive" and another with a "normative" conception:

- In the "positive" approach, agriculture is described as being multifunctional by nature and is analyzed through the concept of externality.

- In the "normative" approach, multifunctionality is defined as the set of contributions which agriculture conveys to the economic and social development of a given society.

The above mentioned issues present an analytical and definitional framework for the concept of multifunctional agriculture. As a result of current trends in the global economy, there is a need for a re-definition of the role of farms in rural areas (see also Marsden et al. 2002). The agricultural sector constitutes only a part of the activities of the rural economy and rural society. It is in this context that Bowler et al. (2002) have discussed 


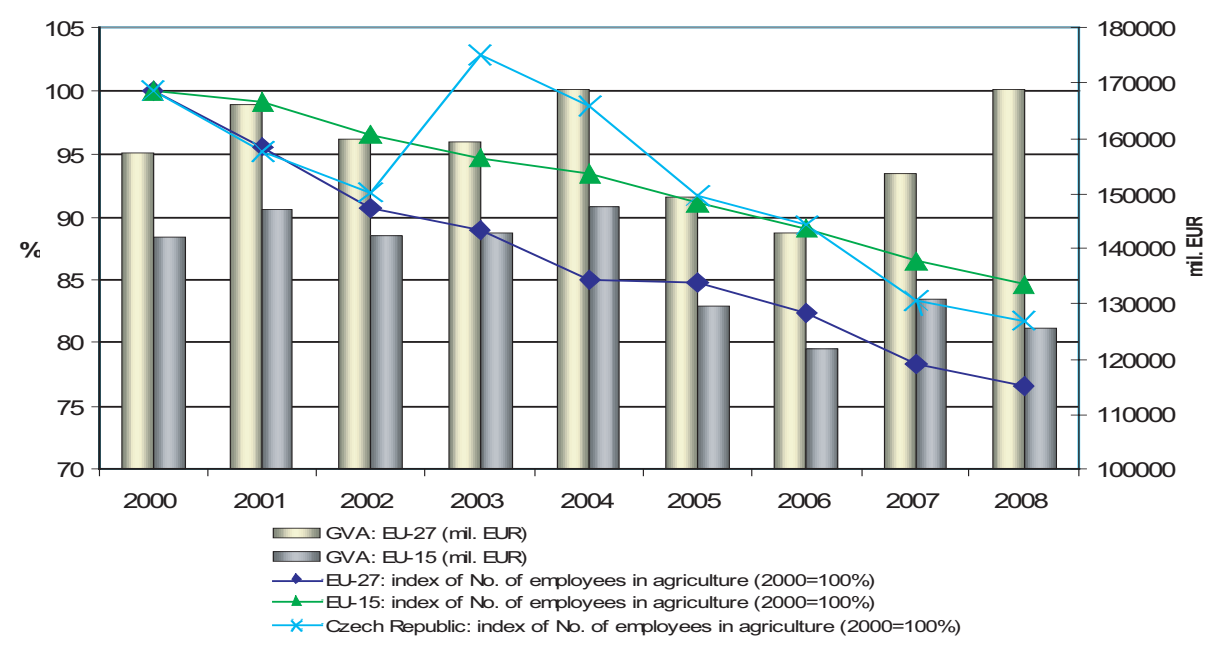

Figure 1. Development of employment in the agriculture sector in the EU-15, EU-27 and the Czech Republic and the development of agriculture GVA in EU-27 and EU-15 in the period 2000-2008 .

Source: Author's own elaboration according to data of Eurostat (2008a), Eurostat (2008b).

the postmodern approach to the concept of rural development and have emphasized the importance of acknowledging people's everyday interpretations of the concept of rurality (Bowler et al. 2002, p. 4). We are therefore talking about the long-term shift from the paradigm of agricultural productivism to a post-productivism period (see also Ilbery 1998). On the other hand, Wilson (2007) has argued that "productivism and post-productivism constitute extreme ends of a spectrum of agricultural and rural decision-making pathways within which the concept of multifunctionality can be theoretically anchored" (Wilson 2007, p. 113).

Bureau (2002, pp. 86) has emphasized two basic goals of the multifunctional agriculture support. The first is to maintain special treatment for this sector within the WTO. The second is to provide reasonable, flexible multilateral trade rules which would allow the various countries, on the basis of their respective situations, to implement policies and measures that would satisfactorily address non-trade concerns. With regard to the need for having a level of public goods production that cannot be completely disso- ciated from agricultural production, certain farm support is legitimate under this "multifunctional" umbrella.

"Multifunctional" agricultural activities create a large amount of potential for rural areas. These activities could contribute to complex development, which would increase the attractiveness of the rural space. But there are a lot of other activities which are related to non-agricultural sectors which are important when it comes to strengthening the endogenous growth potential of rural areas.

The most significant controversy of multifunctional agriculture can be observed in the indirect support of employment and the stabilising of the settlement structure in rural areas. The OECD (2001, p. 13) has argued that rural employment related to agriculture is an input either of commodity production or of wider agro-food industries, and cannot be considered as a non-commodity output of agriculture or as an externality. Nonetheless, it may have an impact on society, which might be considered as constituting externalities (for example, slowing the migration from rural to urban areas). 
But the extent and role of agriculture is continuously diminishing in rural areas (see also Fig. 1) and the overall impact of such subsidies might be doubtful. The argument for agricultural support on the basis that it provides stabilisation for farms has been attacked by Baldwin and Wyplosz (2008, pp. 231). They have stressed that around $80 \%$ of agricultural output is derived from large and effective farms. Therefore, according to Baldwin's assessment, around $20 \%$ of farms receive approximately $80 \%$ of EU CAP expenditure. Korcelli (2008) has mentioned another territorial problem of such policy impacts in that a major retreat from $C A P$, while detrimental to some peripheral regions, might also hit hard some of the EU core regions which have been the main beneficiaries of this policy for a long time (Korcelli 2008, p. 42). The issue of the relationship between EU CAP II. pillar subsidies and employment in the context of the case study of the Czech Republic is analysed in the penultimate section of this paper.

The multifunctionality of agriculture makes new demands for society, such as changing society's and consumers' attitudes towards food, new interest in the rural area and its environment, and new socio-cultural demands for agriculture. These interests have a different urgency and importance for different countries within the EU. The rediscovery of the multifunctionality of agriculture is mainly a result of societal changes and to a much lesser extent is the result of changes in policy. New societal demand was the first stimulant and policy just reacted to this new situation. In general, this was the result of changing life styles that placed increasing importance on the quality of nutrition, that had greater leisure time, whilst also having a greater interest in environmental quality, including rural landscapes and their aesthetic and recreational functions. Policy responds to these societal changes by, for example, offering programmes that reward farmers for producing those (immaterial) goods that society likes to have (Knickel 2001).

The multifunctionality of agriculture raises many ambiguous issues which are more closely related to its normative definition. According to Shucksmith et al. (2005, p. 10), there are two competing paradigms, which vary in dominance over time and have led to a fragmentation of the EU CAP into pillars, resulting in a move away from common policies towards regional and national policies, a growing diversity of instruments and new approaches in agricultural policy with the aim of producing public goods.

Competing paradigms, which are interventionist (they emphasise agricultural production and multifunctional agriculture) and neo-liberal (that advocate a rural development agenda), caused the EU CAP to fragment into two pillars. The first focused on direct payments to farmers, which are conditioned by the fulfilment of cross-compliance rules that have a multifunctional dimension. The second pillar is aimed at complex rural development which is interconnected with the multifunctional character of farming. Nonetheless, the major part of II. pillar expenditure has an agricultural character and therefore there is a conflict between the complexity of rural development and support for multifunctional agriculture (Caffyn et al. 2005). Wilson (2007) has emphasized, that it is important to distinguish between multifunctional agricultural space and multifunctional rural space. Multifunctional agriculture space is, therefore embedded in a less well delineated concept of multifunctional rural space (Wilson 2007, pp. 224).

The aforementioned paradigms are considerably different, especially the contrast between the British and French approaches (Lowe et al. 2002). France, as a major net beneficiary of the CAP, has traditionally been a staunch defender of it and the leader of the protectionist wing (it embodies the interventionist approach). Whereas the UK, as a net contributor, has traditionally been antipathetic to the CAP and is the leader of the liberalising wing (the neo-liberal approach). According to Wilson's (2007) approach to analysing the multifunctional rural/agricultural space, the UK is promoting the concept of a multifunctional rural space in the EU CAP reforms, and, on the other hand, France is advocating a key 


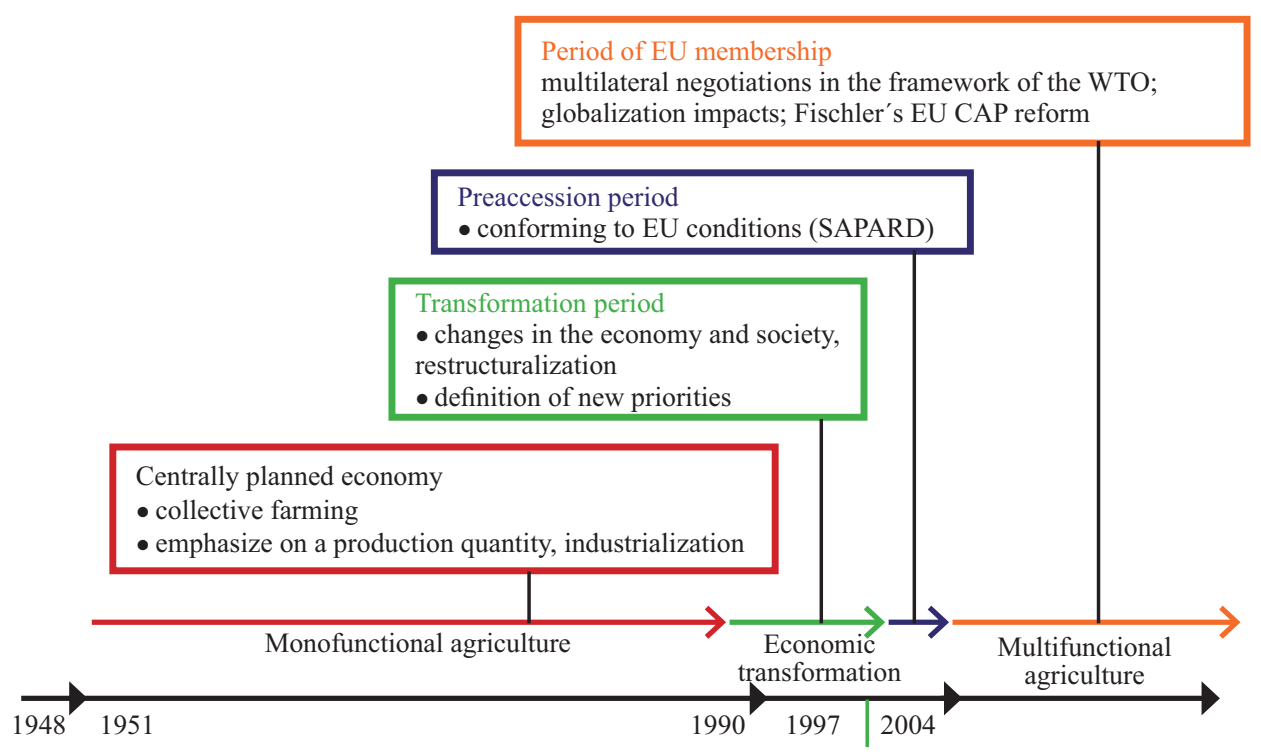

Figure 2. Genesis and development of multifunctional agriculture in the Czech Republic. Source. Author's own elaboration according to Hadyński (2006).

role for multifunctional agricultural space in rural areas and the EU CAP.

In the framework of this analysis, we can claim that the British and French approaches represent border lines. Other EU countries are applying approaches which are between the presented border lines. In the next part, we analyse other examples of EU countries and their approach to the concept of multifunctionality.

\section{ANALYSIS OF APPROACHES TO MULTIFUNCTIONAL AGRICULTURE IN SELECTED EU COUNTRIES}

A significant change has occurred in connection with the new EU agricultural policy. A new model for the agricultural sector that is characterised by its multifunctional and alternative nature was proposed in Agenda 2000 and in the so-called Fischler's EU CAP reform. The result of this Agenda was changes in national agro policies, as can be seen from following examples:
Italy issued in 2001 three legislative guideline decrees (as part of Law no. 57), which aimed to modernise agriculture, forestry, fishing and hydro-culture sectors. In particular, Legislative Decree No. 228 of May 2001, titled "Orientation and modernization of the agricultural sector according to Article 7 of the Law no. 57/2001" introduces important legal innovations and judicial devices that aim to supply a modern idea of what constitutes an agricultural activity. The guideline law also introduces some new tools for public intervention as an answer to the increased request for larger autonomy in the programming and defining of interventions at the local level. The definition of the Rural District as an instrument can be interpreted as a step in this direction. Consequently, the definition of the farmer's role in rural areas has changed and is now free from its historical link with the land. Instead of this previous role, the farmer's activities are connected to the presence of a biological cycle in the current programming period. At the same time, the number and types of activities that can 
be carried out has increased: agro-tourism, direct sales, the possibility of even buying and commercializing products coming from other farms etc.

In the Netherlands new efforts have been directed towards strengthening landscape policy, goals, the instruments and the financial means of the existing policies. A new note was written in 2000, which replaced the Landscape Note and three other policy plans: "Nature for people, people for nature; note on nature, forest and landscape in the $21 \mathrm{st}$ century". The perspective of the landscape section in this latest policy document is "to strengthen the quality and identity of the rural area by mobilising farmers and by better utilising the biological diversity within production systems". Special emphasis is paid to the wider development of rural areas.

In Germany, a gradual change in public perceptions started as a result of the implementation of major agricultural policy reforms at the national level in the period 20012004. The encouragement of responsible farming has been one of the key objectives of the Agrarwende which represented a radically different agenda. This reform placed food safety and quality, transparency, its environmental friendliness, production and animal welfare at the heart of German agricultural policy. Knickel (2005) has explained that the new orientation was clearly expressed in the Regionen Aktiv - Land gestaltet Zukunft pilot programme that was instigated by the Ministry at the end of 2001. The political agenda for the period 2007-2013 places much more emphasis on sustainable farming systems, and it encourages farmers to see the changes in wider society as a challenge and an opportunity.

The 1999 Agricultural Bill in France created the "Land-based Production unit Contract" (contract territorial d'exploitation, CTE). CTE was a five year individual contract between the farmer and the government, inserted into a collective regional approach. The farmer commits himself to a certain number of actions that are related to:

- environmental and territorial objectives (such as the preservation of biodiversity, the maintenance of landscape and the improvement of water quality);

- economic and social objectives (the quality of products, creation of employment, diversification of activities).

The proposals were scrutinized and selected by a regional committee according to local socio-economic, environmental and territorial specifities and priorities. The concept of CTE was substituted in 2003 by the Sustainable Agriculture Contract (Contract d'agriculture durable, CAD). But the contractual "normative" approach was maintained.

The main innovation of the CTE approach was a grouping of individual types of local activities and aligning them with national priorities. The activities of multifunctional agriculture were specifically emphasised.

\section{THE GENESIS OF MULTIFUNCTIONAL AGRICULTURE IN THE CASE OF THE CZECH REPUBLIC}

What about the situation of multifunctional agriculture in the Czech Republic? Is it possible to illustrate the development of this issue through several periods? Fig. 2 shows the time axes of changes in the Czech Republic. The system of a centrally planned economy had been ended by 1990 . The agricultural sector in the communist period was characterised by its monofunctional farming on large lands, the sole aim of which was reaching the required quantity of products without the ownership rights to agricultural land.

After 1990, and the so-called "Velvet revolution", the transformation of the economy also began in agriculture. This process was accompanied by a dramatic decrease of farm incomes in rural areas. New priorities for the economy were presented which did not sufficiently reflect the multifunctionality of the agricultural sector. This period evolved into the preaccession period and the Czech Republic became a candidate country for EU membership. In 2000, the Czech Republic started to implement a special EU preaccession programme, SAPARD, 
Table 1 . Total employment in the national economy - according to the NACE-A01/in 1000 persons *A 01 Agriculture, hunting and related activities + A 02, B Forestry and related activities, fishing and fish breeding

\begin{tabular}{lrrrrrr}
\hline \multicolumn{1}{c}{ NUTS III region } & $\mathbf{2 0 0 4}$ & & $\mathbf{2 0 0 5}$ & $\mathbf{\%}$ change & $\mathbf{2 0 0 6}$ & \% change \\
\hline South Bohemia region & $\mathbf{1 8 . 1 4}$ & $\mathbf{1 0 0 \%}$ & $\mathbf{1 8 . 4 4}$ & $\mathbf{1 0 1 . 6 2 \%}$ & $\mathbf{1 9 . 6 4}$ & $\mathbf{1 0 8 . 2 6 \%}$ \\
South Moravia region & 25.90 & $100 \%$ & 20.77 & $80.18 \%$ & 19.35 & $74.72 \%$ \\
Karlovarsky region & 4.15 & $100 \%$ & 4.29 & $103.46 \%$ & 3.53 & $85.03 \%$ \\
Region Vysocina & 24.63 & $100 \%$ & 24.55 & $99.67 \%$ & 20.99 & $85.22 \%$ \\
Kralovehradecky region & 15.26 & $100 \%$ & 12.57 & $82.40 \%$ & 10.28 & $67.36 \%$ \\
Liberecky region & 6.80 & $100 \%$ & 3.90 & $57.35 \%$ & 4.70 & $69.12 \%$ \\
Moravskoslezsky region & 15.93 & $100 \%$ & 16.50 & $103.62 \%$ & 14.61 & $91.73 \%$ \\
Olomoucky region & 19.22 & $100 \%$ & 16.62 & $86.46 \%$ & 17.12 & $89.09 \%$ \\
Pardubicky region & 14.21 & $100 \%$ & 11.19 & $78.73 \%$ & 11.13 & $78.31 \%$ \\
Plzensky region & $\mathbf{1 1 . 5 2}$ & $\mathbf{1 0 0 \%}$ & $\mathbf{1 4 . 8 0}$ & $\mathbf{1 2 8 . 4 9 \%}$ & $\mathbf{1 4 . 6 5}$ & $\mathbf{1 2 7 . 2 1 \%}$ \\
Praha & $\mathbf{1 . 6 4}$ & $\mathbf{1 0 0 \%}$ & $\mathbf{3 . 8 6}$ & $\mathbf{2 3 5 . 2 6 \%}$ & $\mathbf{3 . 3 0}$ & $\mathbf{2 0 0 . 9 9 \%}$ \\
Central Bohemia region & 25.90 & $100 \%$ & 22.53 & $86.98 \%$ & 23.20 & $89.56 \%$ \\
Ustecky region & $\mathbf{7 . 9 6}$ & $\mathbf{1 0 0 \%}$ & $\mathbf{9 . 2 3}$ & $\mathbf{1 1 6 . 0 0 \%}$ & $\mathbf{9 . 8 5}$ & $\mathbf{1 2 3 . 8 3 \%}$ \\
Zlinsky region & 10.56 & $100 \%$ & 10.10 & $95.71 \%$ & 9.28 & $87.91 \%$ \\
Total & 201.82 & $100 \%$ & 189.36 & $93.83 \%$ & 181.64 & $90.00 \%$ \\
\hline
\end{tabular}

Source: Author's own calculation according to data of Czech Statistical Office (2008).

which was focused on supporting the issue of multifunctional agriculture and rural development. Nowadays, the Czech Republic as an EU member state must to face several challenges which are related to the process of globalization and also the impact of multilateral negotiations at the level of the WTO which are slowly bringing about a more liberal environment for agriculture.

The Czech Republic could be characterized as a case of the "British" rural development agenda in that it emphasizes the environmental dimension of agricultural rural development. A major part of the EU II. pillar allocation is usually given to less favoured areas and agro-environmental measures. For the Czech Republic's agriculture and rural development policy is specific for its strong coordination at the central level of public administration. This issue is more closed to a French case. There are data only available for the period 2004-2006. The current $\mathrm{Ru}$ ral Development Programme 2007 - 2013 is still being implemented.

\section{ANALYSIS OF THE SUPPORT FOR EMPLOYMENT IN THE CZECH REPUBLIC PROVIDED BY THE EU CAP II. PILLAR IN THE PERIOD 2004-2006}

In the Czech Republic, the EU CAP II. pillar was financed by the HRDP - the Horizontal Rural Development Programme during the period $2004-2006$ ( $75 \%$ of the total II. pillar financial allocation) and OP MARD - Operational Programme for Multifunctional Agriculture and Rural Development (25\% of the total II. pillar financial allocation). The plan for the HRDP included four measures derived from Council Regulation (EC) No. 1257/1999 and two measures for new member states under the Access Agreement. These six measures were focused on support for early retirement from farming (ERF), less favoured areas and areas with environmental restrictions (LFA), agro-environmental measures (AEM), forestry, the setting up of producer groups (SUPG) and technical assistance. Preference and the largest allocation of funds were initially given to measures that had existed before the establishment of 
Table 2. Number of job positions affected by HRDP grants in 2004 - 2006

\begin{tabular}{lrrrrrrrr}
\hline \multirow{2}{*}{ Region } & \multicolumn{3}{c}{ AEM+LFA } & \multicolumn{4}{c}{ AEM+LFA+Forests } & \multicolumn{3}{c}{$\begin{array}{c}\text { AEM+LFA+ } \\
\text { Forests+ERF* }\end{array}$} \\
\cline { 2 - 9 } & $\mathbf{2 0 0 4}$ & $\mathbf{2 0 0 5}$ & $\mathbf{2 0 0 6}$ & $\mathbf{2 0 0 4}$ & $\mathbf{2 0 0 5}$ & $\mathbf{2 0 0 6}$ & $\mathbf{2 0 0 5}$ & $\mathbf{2 0 0 6}$ \\
\hline Prague & 0 & 1150.92 & 1339.55 & 0 & 1359.42 & 1697.16 & 1359.42 & 1699.58 \\
SouthBohemia & 11347.04 & 11374.12 & 12019.97 & 11482.15 & 11693.87 & 12848.77 & 11745.06 & 12875.44 \\
Jihomoravsky & 3011.01 & 3273.01 & 3522.83 & 3305.70 & 3924.20 & 4699.46 & 4021.00 & 4716.82 \\
Karlovarsky & 3047.09 & 2914.83 & 3715.79 & 3047.09 & 2936.04 & 3782.31 & 2936.99 & 3782.31 \\
Vysocina & 7063.59 & 6959.17 & 7528.25 & 7620.45 & 8150.56 & 9801.43 & 8239.55 & 9827.61 \\
Kralovehradecky & 5046.98 & 4976.95 & 4921.98 & 5220.84 & 5641.99 & 6202.88 & 5666.82 & 6228.21 \\
Liberecky & 5736.61 & 5408.13 & 6017.01 & 5900.80 & 5625.32 & 6534.90 & 5650.51 & 6534.90 \\
Moravskoslezsky & 6282.24 & 5437.33 & 5554.73 & 6398.07 & 5651.98 & 5908.04 & 5664.00 & 5923.62 \\
Olomoucky & 6640.61 & 6946.41 & 6387.43 & 6676.06 & 7111.66 & 6729.16 & 7146.13 & 6737.71 \\
Pardubicky & 3970.71 & 3950.35 & 4046.65 & 4203.57 & 4480.02 & 4823.32 & 4515.94 & 4845.27 \\
Plzensky & 6793.80 & 6726.10 & 7214.37 & 6923.30 & 7055.49 & 8194.44 & 7093.98 & 8216.54 \\
Central Bohemia & 4862.60 & 4940.72 & 5015.93 & 5086.22 & 5540.09 & 6369.59 & 5663.03 & 6428.20 \\
Ustecky & 5251.62 & 5514.44 & 5295.88 & 5258.98 & 5544.90 & 5400.95 & 5635.41 & 5405.70 \\
Zlinsky & 5246.34 & 4892.47 & 5079.20 & 5468.20 & 5297.00 & 5649.36 & 5328.11 & 5654.15
\end{tabular}

TOTAL

74300.24 74464.94 77659.57 76591.43 80013.52 88641.76 80667.93 88876.07

Source: Author's own calculation based on data of SAIF (2008) and FADN (2008)

* ERF measure started to be implemented in 2005.

the HRDP and therefore with which farmers were already familiar (LFA, AEM and Forestry). Dwyer et al. (2007) have described this approach as a typical case of institutional conservatism.

The HRDP was primarily focused on environmental protection and less wasteful farming methods, and only tangentially on changing the structure of the rural population or adapting to the market. This can be seen in the breakdown of funds (LFA, AEM).

The answer to the research question of the extent to which the programme has contributed to the maintenance of farm and offfarm employment, is presented in Table 2, which presents data on the development of employment in agriculture in 2004-2006 according to changes in individual regions. In view of the fact that the HRDP was primarily directed towards the protection of the environment and environmentally sensitive farming methods, financial support from the programme might have affected employment only indirectly - as a positive external effect. This represents the whole issue of multifunctional agriculture.

Resources received from the HRDP, such as within the LFA support, might have directed the recipients to extend their farms and to increase the number of employees working on the agricultural holding or to at least maintain the original number of employees. This support might have had a similar effect on activities relating to agriculture (such as processing and selling products) or on activities otherwise relating to it (such as agro-tourism).

The importance of employment in agriculture is different in each of the NUTS 3 regions in the Czech Republic. The share of employment in agriculture is highly important in the Vysocina region because it is 2.5 times higher than the national average 
for this sector. A higher than average level of employment in agriculture can also be found in the following NUTS 3 regions: in the South Bohemia region, the Pardubicky region and the Olomoucky region.

In the analysed period 2004-2006, almost all regions in the Czech Republic witnessed a downward trend in employment in agriculture. Four regions bucked the overall trend: Prague, Ustecky, Plzensky and the South Bohemia region. (see Table No. 1).

From 2004 to 2006 there were increases in employment in Prague (200\%), in the Plzensky region (127\%), in the Ustecky region $(123 \%)$ and in the South Bohemia region $(108 \%)$.

Employment in agriculture plays only a marginal role in Prague, which is a capital city and is therefore a metropolitan area. The Ustecky region with 9,850 employees in 2006 is also one of the regions where employment in agriculture is not crucial for the development of the region. Therefore, the analysis will pay no further attention to these regions.

The situation is different in the regions of South Bohemia and Plzensky. But, in order to be able to evaluate the value of these data and the possible influence of the HRDP measure, it is necessary to compare them with the amount of support paid from the HRDP in individual regions. The amount of support paid to these regions from the HRDP programme is shown in Fig. 3.

Fig. 3 illustrates the financial support paid within individual regions from all the supported grant programmes. The largest

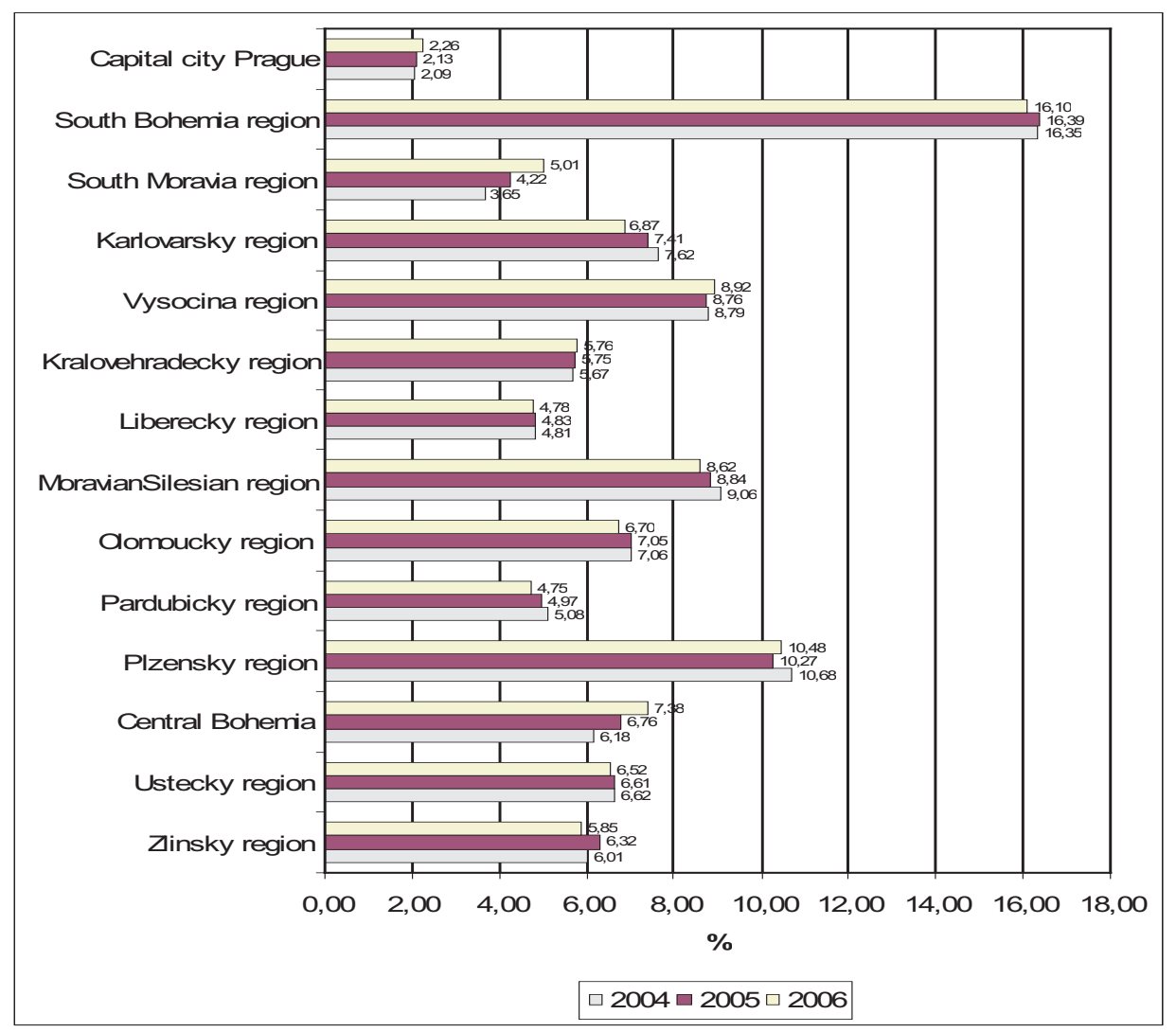

Figure 3. Financial support of the HRDP by NUTS III regions in the CR.

Source: Author's own calculation based on data of SAIF (2008). 
amount of payments was provided in the South Bohemia region which received over $16 \%$ of all payments paid to the regions. The Plzensky region is the second; and Vysocina and Moravskoslezsky regions share the third place, where payments amount to almost $9 \%$ of all the payments paid. The presented analysis implies that a certain connection can be found between the increase in employment and the support that the HRDP provides in the two regions of South Bohemia and Plzensky. There was an increase in employment in both of these regions and the regions also received the largest amount of HRDP financial support.

The previous analysis has tried briefly to explore the notion as to whether any relationship exists between the HRDP and employment levels in agriculture. It has attempted to make the analysis more specific by calculating a potential number or job positions which might have been positively affected by the financial support that the HRDP provides. The calculation is based on a methodology in which the total area in individual regions supported from the HRDP is divided by the number of hectares per 1 employee (SAIF and FADN data, Table 2). It is clear from these calculations that the number of jobs potentially affected by HRDP payments increased in all regions in the given period. A list of regions arranged by the number of supported jobs almost agrees with a list of regions arranged according to the amount of the grant they received.

\section{CONCLUSIONS}

Multifunctional agriculture is, on the one hand, a very broad issue in terms of definition, but on the other hand, it is a very narrow occupation in terms of the rural development scenario. Multifuncionality and its relationship to rural development is still characterised more by questions than clear and understandable answers. The paper has presented several approaches to the concept of multifunctionality by selected EU member states.
Five case studies, which were analyzed by the authors of this paper, showed two views on the multifunctionality concept in agriculture:

- interventionist - a strong relationship of public goods production with agricultural production (France, Italy);

- neo-liberal - the environmental dimension of multifunctional agriculture with an emphasis on the rural agenda (the United Kingdom, the Netherlands, Germany and also, partially, the Czech Republic).

The case studies described a specific situation within a certain locality or region (Italy, France and the Netherlands) while others (the Czech Republic and Germany) dealt with agricultural functions at the national level.

The theoretical discussion of the employment and stability of farmers within rural areas due to the support of multifunctional agriculture policy was analyzed in the Czech case study.

The analysis of public expenditure regarding employment in agriculture shows a certain relationship (although not a very strong one) with HRDP support in the Czech Republic. It is necessary to stress that the HRDP did not have an objective for enhancing employment in rural areas. The comparison of the amount of the support and the level of employment identified a certain connection in the two regions of South Bohemia and Plzensky. These regions are among the major recipients of financial support and employment increased from 2004 to 2006 . A calculation of potential employment support that the programme provides according to region almost corresponds to the levels of HRDP payment to these regions. It must be borne in mind that the three year monitoring period for this programme was comparatively short. Therefore, it is necessary to analyze these issues over a longer period, especially when preparing a future analysis on the territorial impact of EU CAP $2^{\text {nd }}$ pillar on the basis of data of the programme for the periods 20042006 and 2007-2013. 


\section{ACKNOWLEDGEMENTS}

This paper is the result of research findings funded by a financial grant project from the EU No. 505297 Capitalization of Research Results on the Multifunctionality of Agriculture and Rural Areas (MULTAGRI) (financed by the EU and which began in 2004) and a project of NAZV, Czech Ministry of Agriculture, Rural area a space for living or survival, which is being undertaken with the support of EF faculty, University of South Bohemia.

\section{REFERENCES}

Baldwin, R., Wyplosz, Ch. (2008), Ekonomie evropské integrace [The economics of the European Integration], Prague, Grada Publishing.

Bowler, I.R., Bryant, C.R. and Cocklin, C. (eds.) (2002), The Sustainability of Rural Systems: Geographical Interpretations, Kluwer Academic Publishers, Dordrecht.

Bureau, J. Ch. (2002), Enlargement and reform of th EU Common Agricultural Policy - impacts on the western hemisphere countries, Inter-American Development Bank, Washington D.C.

Bureau, J.Ch., Mahé, P.L. (2008), CAP reform beyond 2013: An idea for a longer view, Notre Europe.

Caffyn, A. and Dahlström, M. (2005), UrbanRural Interdependecies: Joining Policy in Practice, Regional Studies, Vol. 39.3, pp. 283-296.

Czech Statistical Office (2008), Total employment in national economy - according to the NACE-A01, A 01 Agriculture, hunting and related activities + A 02, B Forestry and related activities, fishing and fish breeding.

Dwyer, J., Ward, N., Lowe, P. and Baldock, D. (2007), European Rural Development under the Common Agricultural Policy's „Second Pillar“: Institutional Conservatism and Innovation, Regional Studies, Vol. 41.7, pp. $873-887$.

EUROSTAT (2008a), Agricultural Labour
Input Statistics: indices $(2000=100)$, available from: <http://epp.eurostat. ec.europa.eu/portal/page? pageid $=0,1$ 136206,0 45570467\&_dad=portal\& schema $=$ PORTAL $>$, accessed December 202008.

EUROSTAT (2008b), Economic accounts for agriculture - values at current prices - GROSS VALUE ADDED AT BASIC PRICES, available from:

$<$ http://epp.eurostat.ec.europa.eu/extraction/ retrieve/en/theme5/aact/aact_eaa01?Out putDir=EJOutputDir_1392\&user=unkno wn\&clientsessionid $=0$ BC 3 DA $90125 \mathrm{~A} 1$ C1FDDA79D9CFFB2043E.extraction 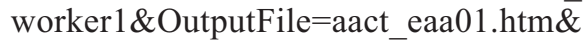 OutputMode $=$ U\&NumberOfCells $=324 \&$ Language $=$ en $\&$ OutputMime $=$ text $\% 2$ Fht ml\&>, accessed December 202008.

FADN (Farm Accountancy Data Network) (2008) - data provided for the ex-post evaluation of the HRDP (Horizontal Rural Development Programme 2004-2006 for the Czech Republic).

Hadyński, J. (2006), Presentation within the conference Third Seminar of the European Academy of Regions, July 2006, Europaische Rechtsakademie Trier, Germany.

Ilbery, B. (1998), The Geography of Rural Change, London, Longman.

Johnson, G.T. (2001), The rural economy in a new century, International Regional Science Review 24, 1: 21-37.

Knickel, K. (2001), The marketing of Rhöngold milk: an example of the reconfiguration of natural relations with agricultural production and consumption, Journal of Environmental Policy and Planning, 3 (2): 123-136.

Korcelli, P. (2008), Scenarios on the Territorial Future of Europe: A Commentary and Further Implications, Europa XXI, 18: $39-46$.

Mahé, P.L., Ortalo-Magné, F. (1999), Five proposals for a European model of the countryside, Economic Policy, 14 (28): 87-131.

Marsden, T., Bristow, G. (2002), The social management of rural nature: understand- 
ing agrarian-based rural development, Environment and Planning A, 34: 809 825.

MoA CR (2007), Zpráva o stavu zemédělství ČR za rok 2007 [Report on the state of agriculture in the Czech Republic 2007)], Ministry of Agriculture of the Czech Republic.

OECD (2001), Multifunctionality - towards an analytical framework, Organisation for Economic Cooperation and Development.

SAIF (State Agricultural Investment Fund) (2008) - data provided for the ex-post evaluation of the HRDP (Horizontal Rural Development Programme 2004-2006 for the Czech Republic).
Shucksmith, M., Thompson J.K., Roberts, D. (2005), The CAP and the Regions: the Territorial Impact of the Common Agricultural Policy, Oxfordshire, Cambridge: CAB International.

Tangermann, S. (2006), The Future of the CAP under WTO Reform Pressure, a presentation delivered at a conference on Vision of a Long-Term Agricultural and Rural Development in EU, Prague.

Ward, N. (2002), Setting the next agenda? British and French approaches to the second pillar of the Common Agricultural Policy, Journal of Rural Studies, 18: $1-17$.

Wilson, G.A. (2007), Multifunctional agriculture: a transition theory perspective, Wallingford, CAB International. 